Please do not remove this page

RMIT

UNIVERSITY

\title{
How do amenity migrants learn to be environmental stewards of rural landscapes?
}

Cooke, Benjamin; Lane, Ruth

https://researchrepository.rmit.edu.au/esploro/outputs/9921859869801341/filesAndLinks?institution=61RMIT_INST\&index=null

Cooke, B., \& Lane, R. (2015). How do amenity migrants learn to be environmental stewards of rural landscapes? Landscape and Urban Planning, 134, 43-52.

https://doi.org/10.1016/j.landurbplan.2014.10.006

Document Version: Accepted Manuscript

Published Version: https://doi.org/10.1016/j.landurbplan.2014.10.006

Repository homepage: https://researchrepository.rmit.edu.au

(C) 2014 Elsevier B.V. All rights reserved.

Downloaded On 2023/04/26 19:29:02 +1000

Please do not remove this page 
Thank you for downloading this document from the RMIT Research Repository.

The RMIT Research Repository is an open access database showcasing the research outputs of RMIT University researchers.

RMIT Research Repository: http://researchbank.rmit.edu.au/

\section{Citation:}

Cooke, B and Lane, R 2015, 'How do amenity migrants learn to be environmental stewards of rural landscapes?', Landscape and Urban Planning, vol. 134, pp. 43-52.

See this record in the RMIT Research Repository at:

https://researchbank.rmit.edu.au/view/rmit:31169

Version: Accepted Manuscript

Copyright Statement: (c) 2014 Elsevier B.V. All rights reserved. Creative Commons Attribution-NonCommercial-NoDerivatives 4.0 International License

Link to Published Version:

http://dx.doi.org/10.1016/j.landurbplan.2014.10.006 
1 How do amenity migrants learn to be environmental stewards of rural landscapes?

3 COOKE, Benjamin, RMIT University, Melbourne, ben.cooke@ rmit.edu.au

4 LANE, Ruth, Monash University, Melbourne, ruth.lane@monsh.edu

$6 \underline{\text { Abstract }}$

7 The changing socio-ecological dynamics in rural landscapes associated with amenity migration

8 in post-industrial nations such as Australia has implications for environmental management.

9 The number of non-farming landholders now occupying regions once valued primarily for

10 agriculture has increased rapidly in the past decade, with property turnover rates in some rural

11 Australian regions as high as 50 percent. Given amenity migrants can shape rural ecologies

12 through land management practice, it is vital that we understand how these management

13 practices are informed. As such, we ask: how do amenity migrants learn to be environmental

14 stewards of their land? We focus specifically on how the tangible interaction between

15 landholder and landscape through experiential learning contributes to the emergence of

16 environmental stewardship. We adopt a conceptual premise that recognises the agency of the

17 biophysical landscape in the experiential learning process. To explore how amenity migrants

18 learn about stewardship we undertook a qualitative case study in the hinterland regions of

19 Melbourne, Australia. We found that initial struggles to implement land management informed

20 by prior urban lifestyles saw landholders turn to experiential learning to fill a void of

21 understanding about ecological processes and management practice. Over time, these

22 experiences distilled into durable dispositions for environmental stewardship that directed

23 either a passive (hands-off) or active (hands-on) approach to land management. Understanding

24 how amenity migrants learn to be environmental stewards has implications for the location and

25 timing of environmental policy engagements with new rural landholders. 
26 Key words: amenity migration; experiential learning; private land; stewardship; dwelling;

27 exurban

28

29 Highlights:

30 - Nonhuman agency is central to experiential learning in environmental management

31 - Durable dispositions for stewardship emerge through experiential learning

32 - Environmental policy must consider the timing and location of landholder engagement

33

34 Full contact details for corresponding author:

35 Benjamin Cooke

36 GPO Box 2476 Melbourne, VIC 3001

$37 \quad$ Australia

$38+61399259943$

39 ben.cooke@ rmit.edu.au

40

41

42

43

44

45

46

47

48

49

50 


\section{$51 \quad$ 1. Introduction}

52 The increasing migration of non-farming landholders to rural regions is a well-documented

53 phenomenon across many post-industrial nations (Abrams, Gill, Gosnell, \& Klepeis, 2012;

54 Gosnell, 2011; Klepeis, Gill, \& Chisholm, 2009). Areas once valued primarily for productive

55 agriculture have become increasingly valued for their natural, aesthetic and lifestyle qualities

56 (Argent, Tonts, Jones, \& Holmes, 2010; Holmes, 2006). While this paper focuses on Australia

57 specifically, similar trends in rural landscape change have been observed in Canada and the US

58 (Gosnell, 2011), the UK (Phillips, 1993) and across continental Europe (López-i-Gelats,

59 Tàbara, \& Bartolomé, 2009; Van Auken, 2010). The shifting socio-ecological dynamics

60 associated with rural landscape change presents uncertainty about how new rural landholders

61 will manage their land in ways that might differ from productively-orientated farmers (Gosnell,

62 2011; Kondo, Rivera, \& Rullman, 2012; Yung \& Belsky, 2007).

64 This paper is specifically interested in understanding the environmental stewardship of

65 'amenity migrants' (defined below) in the hinterlands of Melbourne, Australia, in order to

66 inform environmental management research and policy. In particular, we ask: how do amenity

67 migrants learn to be environmental stewards? For the purpose of this paper, we adopt a

68 deliberately broad definition of stewardship as the way in which landholders conceive of

69 responsible management of the ecologies on their property, in order to achieve both public and

70 private benefits (Gill et al., 2010; Gill, 2013; Worrell \& Appleby, 2000). This definition differs

71 from more normative definitions aligned with notions of 'best practice' environmental

72 management amongst farmers (Lawrence, Richards \& Cheshire, 2004). Given limited existing

73 understanding of how stewardship is informed amongst amenity migrants we wanted to capture

74 the aspects of stewardship that amenity migrants bring with them to rural landscapes 
75 (Mendham et al., 2012), as well as the stewardship that emerge through inter-relationships with

76 nature over time (Gill, 2013).

\section{1 'Amenity migration' and its environmental management implications}

79 In this paper we adopt the term 'amenity migration' to describe the process of rural landscape

80 transition (Argent et al., 2010; Kondo et al., 2012). The amenity that migrants seek is often

81 associated with the 'natural' values and aesthetics of rural areas, the recreational opportunities

82 they provide and the pursuit of 'the simple life' that is perceived to come with leaving the

83 hustle and bustle of the city (Argent et al., 2010; Halfacree, 2006). Amenity migrants can

84 include retirees (Curry, Koczberski, \& Selwood, 2001), young families and people looking for

85 a second home outside of the city (Kondo et al., 2012). As such, the term 'amenity' is being

86 deployed here in a broad sense, to capture the diverse aspirations of migrants.

88 In terms of environmental impacts, amenity migration can result in the subdivision of farmland

89 into smaller land parcels and increasingly heterogeneous land use, raising concerns about the

90 fragmentation of ecosystems (Carmona-Torres, Parra-López, Groot, \& Rossing, 2011; Gobster

$91 \&$ Rickenbach, 2004). The resultant mosaic of smaller properties can complicate landscape-

92 scale ecological management efforts like habitat restoration or weed removal (Klepeis et al.,

93 2009; Urquhart \& Courtney, 2011). Pressure may also be placed on ecosystems through

94 clearing of vegetation for house blocks, fences and recreational land use. While many in-

95 migrants have an interest in pursuing environmental management on their properties

96 (Mendham, Curtis, \& Millar, 2012) the diversity of actors and land use preferences presents a

97 challenging picture for environmental management.

98

99 The shifting social dynamics associated with amenity migration sees new rural landholders 
100 often possessing a different perspective on rural landscapes than farmers (Cadieux \& Hurley,

101 2009; Klepeis et al., 2009; Mendham \& Curtis, 2010). For example, the pursuit of an 'idyllic'

102 rural lifestyle can manifest in a desire for seclusion on one's land (Meadows, Herbohn, \&

103 Emtage, 2013; Urquhart \& Courtney, 2011; Yung \& Belsky, 2007). As a result, amenity

104 migrants can become very 'property-centric' in their ecological interests (Cadieux, 2011; Gill

105 et al., 2010). A desire for 'getting on with it' (Gill et al., 2010, p321) independently on one's

106 own property contrasts with efforts to work collectively across property boundaries to address

107 ecological challenges - like invasive plants - commonly associated with environmental

108 management in farming communities (Yung \& Belsky, 2007).

110 While amenity migrants may be motivated to pursue environmental management, their

111 potentially limited familiarity with the rural landscapes creates uncertainty around the practice

112 and outcome of their management efforts (Mendham et al., 2012). For example, amenity

113 migrants can be unaware of local weed species (Klepeis et al., 2009), while having minimal

114 experience with practical land management tasks like fencing (Curry et al., 2001). Moreover,

115 the aspirations of new rural landholders to be environmental stewards can be bound up with

116 other land use motives, like recreation (Urquhart \& Courtney 2011) or improving visual

117 amenity (Knoot, Schulte, \& Rickenbach, 2010), which can produce unpredictable

118 environmental outcomes. As such, there is significant uncertainty surrounding our

119 understanding of how environmental stewardship emerges and is materialised in the landscape,

120 given the complex socio-ecological transformations associated with amenity migration.

$122 \quad 1.2$ The environmental stewardship of amenity migrants

123 Amenity migrants' diverse land use interests and potentially limited exposure to rural

124 landscapes suggests their existing ideas of environmental stewardship will be built on as they 
125 establish their amenity lifestyles. In farming contexts, stewardship has been shown to have a

126 strong emergent dimension over time, linked to interaction with the physical landscape and

127 knowledge passed between generations of farmers and amongst farming communities (Trigger,

128 Toussaint, \& Mulcock, 2010; Turner \& Berkes, 2006). As a consequence, the stewardship of

129 farmers shapes the trajectories of ecological change over time, and is a central consideration in

130 environmental policy design and implementation (Burton, Kuczera, \& Schwarz, 2008; Burton,

131 2012; Greiner \& Gregg, 2011; Junge, Lindemann-Matthies, Hunziker, \& Schüpbach, 2011).

132 We suggest that a more in-depth understanding of the on-ground land management practices of

133 amenity migrants could provide an avenue for critical insights into how new rural landholders

134 learn to be environmental stewards (Gill et al., 2010); these insights will have implications for

135 environmental management practice and policy in rural landscapes. Moreover, new

136 experiments with environmental policy that target rural landscapes where amenity migration is

137 occurring means that the implications of emergent stewardship are both timely and critical for

138 policy makers (Cocklin, Mautner, \& Dibden, 2007; Cooke, Langford, Gordon \& Bekessy,

139 2012). To explore how stewardship emerges we conducted interviews and participant

140 observation with landholders to interrogate the experiential learning that occurs through the

141 interactions between amenity migrants and the rural landscapes they come to inhabit.

\section{$143 \quad 1.3$ Environmental stewardship, land management practice and experiential learning}

144 The land management practices of amenity migrants present a useful starting point for

145 interrogating the emergence of environmental stewardship. Indeed, we are specifically

146 interested in how stewardship emerges through the practice of managing, interacting with and

147 observing the landscape in which one is situated. While we recognise that there are a number

148 of avenues for learning that are relevant for exploring emergent stewardship, like social

149 learning (Keen \& Mahanty, 2006; Pannell et al., 2006) and NRM extension information (Reed 
150 et al., 2010), we posit that experiential learning, or learning-by-doing, holds particular

151 relevance. There are two key reasons for focusing on experiential learning.

153 Firstly, extensive research on experiential learning in NRM and farming has highlighted the

154 prominent role of learning-by-doing and trial-and-error management in learning about

155 ecological function and environmental management (Armitage et al., 2009; Berkes \& Turner, 156 2006; Palis, 2006; Pannell et al., 2006). As ecologies change through human intervention and

157 natural processes, trial and error management becomes pivotal for learning how to respond to

158 changing landscapes (Armitage et al., 2009; Berkes \& Turner, 2006). Given the knowledge that

159 farmers possess about ecological processes that is generated through the lived experience of

160 landscape over time (Knapp \& Fernandez-Gimenez, 2009; Palis, 2006; Van Herzele,

161 Dendoncker, \& Acosta-Michlik, 2010), the role of experiential learning in the emergence of

162 environmental stewardship amongst amenity migrants requires interrogation.

164 Secondly, experiential learning presents an avenue for bringing much needed research attention

165 to the agency of the biophysical landscape, or 'nonhuman agency', in affecting management

166 practice and environmental stewardship. Following Ingold (2000), we progress the idea that the

167 biophysical environment is an active agent in shaping management practice. Agency has

168 traditionally been defined as a human capacity for action, expressed through the ability to

169 make choices and develop skills. In saying that landscapes can have agency, we are

170 suggesting that landscape features like plants have a 'power' to affect management practices

171 through their growth and spread, for example (Head \& Atchison, 2008). While this power

172 may not be conscious and intentional in the same way as human agency, it is nonetheless

173 significant. By recognising landscape agency, we suggest that management practice can be

174 thought of as a type of 'dialogue' between people and the landscape over time, rather than the 
175 landscape being a passive recipient of autonomous human action.

177 The nonhuman agency exerted by the landscape can shape, propagate and complicate

178 management practice (Cloke \& Jones, 2001). For example, the growth of trees in an orchard

179 (Cloke and Jones 2001) or the dieback of a front lawn (Robbins, 2007) can initiate human

180 management activities, emphasising the active role of plants in shaping stewardship practice

181 and goals. Taking nonhuman agency into account focuses attention on how people's

182 interactions with the environments of their everyday lives can play a powerful role in

183 generating environmental stewardship (Gill, 2013; Macnaghten, 2008).

\section{2. The application of experiential learning and dwelling perspective}

186 Experiential learning theory is described as "the process whereby knowledge is created through

187 the transformation of experience" (Kolb, 1984, p. 41). According to the original definition

188 from Kolb (1984), learning occurs through a continuous cycle of action and reflection. The

189 active experimentation (immersion in the world) and reflective observation (observing

190 processes and reflecting on the outcomes) dimensions of experiential learning are highly

191 relevant to environmental management, which explains its widespread adoption in this field

192 (Fazey, Fazey, Salisbury, Lindenmayer, \& Dovers, 2006; Kolb, Boyatzis, \& Mainemelis, 2001;

193 Leeuwis, 2004; Pannell et al., 2006). Borrowing from more recent critiques of the concept

194 (Lankester, 2013; Leeuwis, 2004; Seaman, 2008), we take a view that experiential learning is

195 not a closed, cyclical process of individual experience, reflection and cognition, but an open

196 process integrated with wider socio-ecological relations. Important conceptual work has

197 recently been done to de-centre the model of the individual learner divorced from a social

198 world that has afflicted experiential learning (see for example Kayes, 2002 and Lankester,

1992013 for an NRM context). However, nonhuman agency, like the spread of invasive plants, 
200 remains largely un-conceptualised. The tangible engagement between people and landscape

201 that often characterises environmental management suggests an important need for such

202 conceptualisations of experiential learning in this field.

204 Here we develop a conceptual premise that connects experiential learning with Heidegger's

205 (1971) dwelling perspective, to create space for the physical landscape as an active agent in the 206 emergence of environmental stewardship. Heidegger developed the concept of dwelling to

207 remedy the Cartesian split of mind from body, suggesting that the act of being is a "worldly

208 activity', and that to ignore this world results in a failure to properly comprehend human

209 existence (Cerbone 2008, p31). Dwelling has been reinvigorated in recent years by a range of

210 scholars seeking to probe the relationships between people and landscapes (Cloke and Jones,

211 2001; Ingold, 2000; Mcnaghten and Urry, 1998). Borrowing from dwelling, we posit that the

212 'ongoing togetherness' (Cloke and Jones, 2001, p651) of people and landscape is a critical

213 relationship for exploring emergent stewardship. Integrating dwelling with experiential

214 learning gives a prominent place to interaction, observation, interpretation and response to the 215 agency of the landscape in the learning process.

217 Figure 1 identifies how experiential learning can be positioned as an influence that interacts

218 with imported land use aspirations and socio-cultural context in shaping the emergent

219 stewardship of amenity migrants. Imported land use aspirations reflect the lifestyle motives

220 that amenity migrants bring with them (noted above), while social and cultural context reflects

221 how the role of social interaction in rural communities and other forms of information

222 exchange can contribute to landholders' emergent stewardship (Larsen \& Hutton, 2011;

223 Pannell et al., 2006). 
225 As shown in Figure 1, landscape agency integrates with experiential learning through the

226 process of management practice. The interactions of people with their landscape are ongoing,

227 as landholders 'act' on the landscape through management interventions (weeding, planting

228 etc.), and the landscape 'acts back' (as trees grow, for example). By integrating dwelling, the

229 active experimentation and passive reflection aspects of experiential learning are tied directly

230 to the situated engagement of people with their surrounding environments over time.

232 3. Methodology

$233 \quad$ 3.1 Study area

234 The site of this research project was the hinterlands of Melbourne, Victoria, Australia.

235 Melbourne's hinterland was chosen for this research due to the rapid pace of rural-amenity

236 land use transition in this region over the last few decades (Burnley and Murphy, 2004;

237 Mendham \& Curtis, 2010). Areas on the coast or coastal hinterland within commutable

238 distance to Melbourne have proved most popular (Argent et al., 2010). Our research focuses on

239 two localities within Melbourne's hinterland - the eastern part of the Corangamite catchment

240 and the Bass Valley district. Recent research suggested the likelihood of a 50 per cent turn over

241 in property ownership in the coming decade in parts of the Corangamite catchment (shown in

242 Figure 2) (Mendham and Curtis, 2010). The high rate of property turn-over and shifting land

243 use away from intensive agricultural production in this region is symptomatic of the amenity

244 migration phenomenon in Australia and globally (Abrams et al., 2012; Holmes, 2006). The

245 Bass Valley region experienced a 25 per cent growth in population between 1991 and 2006,

246 placing it amongst the fastest growing regions in Melbourne's hinterland (ABS, 2006). The

247 majority of this population growth occurred outside of existing rural townships, indicating a

248 high rate of subdivision of existing farmland into amenity lifestyle properties (ABS, 2006). 
251 A case study research design allowed us to engage with participants in the context of their

252 surrounding environments in order to explore the emergence of stewardship. The two research

253 methods directed by this research design were narrative interviews and a form of participant

254 observation called the 'walkabout method' (Strang, 2010). The first author carried out both of

255 these research methods with participants. The narrative interviews borrowed from an oral

256 history approach to interviewing, which encourages participants to tell stories about past events

257 and personal experiences (Rosenthal, 2004). However, the oral history approach was adapted

258 to encourage landholders to tell stories about their experiences interacting with and observing

259 their surrounding landscape over time. Participants were prompted for stories about what it was

260 like living on their property, how their landscape had changed over their tenure, and how their

261 land management aspirations and practices had changed over time. These one-on-one

262 interviews were conducted in or around the home of the participant, and aimed at

263 understanding the aspirations that landholders had for managing their property environments

264 when they arrived, the early management activities they conducted and what they learned

265 through those activities.

267 Following the interview process, the researcher walked participants' properties with them to

268 explore how management practices had materialised in the landscape over time. The walkabout

269 method was vital as it explicitly acknowledges that the physical environments that are of

270 importance to people's lives will serve as repositories of memory of experience in those spaces

271 (Lane, 1997; Strang, 2010; Trigger et al., 2010). Indeed, as the researcher walked the property

272 with participants, evidence of land management embodied in the landscape (like fences and

273 tree plantings) served as catalysts for stories about how those management practices were

274 informed and conducted, how subsequent practices might have evolved as a result of 
275 management success or failures, and what had been learnt about ecological function along the

276 way. During the walks, photos were taken of management activities and ecological features

277 encountered. Notes were also recorded in a research journal to help document the walkabout

278 process, and expanded upon later in greater detail. The participant led the walk and told stories

279 about management activities, prompted by the researcher when passing visible management

280 interventions. The walkabout method allowed the researcher insights into landscape change,

281 how landholders interpreted those changes and how landholders learned to be stewards through

282 their management practices. These walks averaged around two hours in length.

28421 landholders were interviewed between June and October 2010 in the two localities shown in

285 Figure 2. As identified in Table 1, the length of tenure of participants in these locations ranged

286 from six years to over 20 years, providing a wide time frame over which the management

287 practices of landholders had been conducted and reflected upon. The majority of landholders

288 moved from suburban Melbourne, with three moving from smaller residential properties in

289 rural townships. Only two landholders who previously lived in rural townships moved to a

290 larger amenity property in the same district, meaning the vast majority of in-migrants were

291 unfamiliar with their region prior to moving there. Three landholders had some previous

292 farming experience, with two having retired on the property they previously farmed. The

293 ecological characteristics of landholders' properties are included in Table 1 to demonstrate the

294 heterogeneous ecologies and land uses present on the properties. The extent of vegetation

295 clearing noted in the form of farm paddocks, modified vegetation and regenerating ecologies is

296 indicative of the history of intensive agricultural land use in both of the study localities.

298 Also interviewed were four extension officers employed by the Victorian Government to help

299 deliver conservation programs aimed at private land. They provided a valuable perspective on 
300 landholder management learning and practice, based on their lengthy experience dealing with

301 private property owners.

302

303 All interviews were recorded and transcribed, with both transcripts and notes from the

304 participant observation compiled using the qualitative software program NVivo and analysed

305 using an open thematic coding approach (Richards, 2009). Thematic coding directs data coding

306 according to a descriptive characteristic, to build towards a theme that brings holistic meaning

307 to descriptive codes. The thematic coding process helped to retain the context of stories

308 landholders shared about their stewardship, meaning individual codes did not become isolated

309 from the wider narratives of participants.

311 4. Results \& Discussion

312 4.1. Amenity as a 'property-centric' pursuit

313 The 'amenity' that landholders sought through in-migration was tied closely to the private

314 property parcel. Many participants who had migrated from Melbourne spoke of wanting a rural

315 property that was secluded, with greater privacy and separation from neighbours than they

316 enjoyed in their previous suburban neighbourhood. Nine participants from both suburban and

317 rural residential backgrounds expressed a desire to be the autonomous custodians of a patch of

318 land - wanting to 'own a bit of bushland' (Steve) was something many had long coveted.

319 Strong desire for immersion in 'private nature' (Cadieux, 2011, p348) through property-based

320 experiences accords closely with research noted earlier (Gill et al., 2010; Yung \& Belsky,

321 2007). This property-centric focus of amenity migrants sets the scene for understanding why

322 the property parcel is a critical space for learning to be an environmental steward. The diverse,

323 yet property-centric amenity aspirations for land use and management they brought with them 
324 meant that they tacitly engaged with biophysical environment on their property soon after 325 acquisition.

\subsection{Aspiring to an amenity lifestyle through gardening}

328 The formative land management activities conducted by landholders on their properties largely

329 consisted of efforts to establish gardens and ornamental trees around the home. Concerns with

330 gardens, landscape aesthetics and screening out neighbours through tree planting are indicative

331 of their imported lifestyle aspirations. The planting itself was a kind of 'tinkering' (Jim) with

332 the landscape, framed as an individual and recreational activity (Cadieux, 2011; Urquhart \&

333 Courtney, 2011). The decision by 10 landholders to attempt to plant the same species that they

334 had grown or tendered at their previous home, highlighted that past landscape associations and

335 a priori knowledge that landholders brought with them were formative influences on their

336 management practices. Indeed, establishing a garden that connected to one's personal history

337 served as an avenue for bringing a sense of familiarity to an unfamiliar landscape (Cadieux,

338 2011). William, Emma and Sally had all planted ornamental species (rhododendron, Japanese

339 maple and silver birch, respectively) that featured in the gardens of a past suburban home. This

340 reinforced the comfort provided by the ornamental garden; having a 'bush bit' and a 'home bit'

341 (Emma) provided the 'best of both worlds' (William). Establishing a familiar ecology appeared

342 to be independent of the backgrounds of participants or the ecological characteristics of their

343 property. Landholders like Jim and Beatrice, and Nick conducted similar plantings despite

344 different backgrounds and property ecologies (see Table 1). In seeking to create a 'homely' and

345 familiar space (Power, 2009), many participants 'got planting' (Tina) almost immediately.

346 Most of these early attempts at planting did not go as planned, with eight participants citing

347 major failures: 
We tried to plant just a screening plantation [of mixed native and ornamental species] between our property and the next property. But what we've found is planting trees out here doesn't really work. I think the native trees seem to be strong enough and the others just don't survive... What is here is basically what has regenerated. (Hannah)

354 Hannah's struggle to establish ornamental trees reflected a formative experience amongst many

355 participants - a realisation that their imported land management knowledge and aspirations

356 could not be easily applied to their new rural environment. The realisation that "we really had

357 no idea early on' (Steve) was a pivotal catalyst for experiential learning, reinforcing the

358 importance of tensions between people's 'aspirations and perception of reality' (Lankester,

359 2013, p184) as an instigator of experiential learning.

4.3 The transition to experiential learning and the emergence of environmental stewardship

362 For many participants, it was the 'acting back' of the biophysical landscape in response to

363 management interventions - especially the behaviour of plants - that filled a vacuum of

364 knowledge about local ecosystem function. Hannah's attempts to plant non-native ornamental

365 trees that ultimately died resulted in a view that only native species were 'strong enough' to

366 survive in the landscape. Observing the natural regeneration of native species occurring in

367 parallel with the death of the species she planted reinforced the idea that nature was best left to

368 its own devices. The process of implementing a management action and observing the response

369 of the landscape developed specific ideas about ecological function and appropriate

370 management. For William, the initial amenity motivation for living amongst 'native' nature

371 was disrupted by the spread of non-native shrubs from an adjoining property. When attempting

372 to remove these weeds by hand, William observed native birds nesting in them, causing him to

373 question the benefits of removing all exotic species for local fauna. William had learnt through 
374 experience that you could be a counter-productive environmental manager by aspiring to a

375 'pure' ecology of only native flora (Head \& Muir, 2006). Both William and Hannah typified

376 how landholders' direct management actions, and ongoing observation of those actions, could

377 be a catalyst for generating ideas about ecological function and management.

379 By generating ideas about ecological function and land management through experiential

380 learning, participants were developing an overarching disposition for environmental

381 stewardship. We use the term 'disposition' here to refer to a durable mentality for stewardship

382 that reflects a tendency to respond to one's environment in ways that suggest an ongoing

383 association with that environment (Burton, 2012; Cammack et al., 2011; Nordlund and Garvill,

384 2002). Through the types of experiential learning process already outlined, the environmental

385 stewardship of participants took the form of either a passive or active disposition. A passive

386 disposition dictates a hands-off approach to stewardship, while an active disposition shapes a

387 hands-on, interventionist approach. The active stewardship dispositions of landholders like

388 Alice and Sam became evident through a discussion of the changes to vegetation communities

389 on their property.

390

Alice: So we've got all these bushes springing up. It's supposed to be native... but we're not sure.

Sam: As they pop up we just pull them out... we just take them out because otherwise they'd take over.

397 When a protracted drought broke in southeastern Australia in 2010, change began to occur to

398 the bushland on Alice and Sam's property at a rate previously unseen. In the decade prior, 
399 Alice and Sam had come to appreciate a static bushland aesthetic on their property due to a

400 long period of dry conditions that stunted plant growth and spread. However, pioneer acacia

401 species (Acacia pycnantha) were suddenly flourishing, causing a noticeable disruption to this

402 static aesthetic. In response, Alice and Sam actively removed the colonising acacia species to

403 preserve the status quo ecology to which they had become accustomed. Alice's admission that

404 they were aware the species could be native (based on the observation of a similar plant in a

405 local vegetation guidebook) also showed a prioritisation of experiential learning over other

406 information sources - a point we turn to later.

407

408 Active management to maintain a static ecosystem was a common practice amongst

409 participants, with changing ecologies viewed as needing human intervention. As many

410 landholders were only confident in identifying a handful of prominent weed species, the

411 observed colonising behaviour of plants often served as a proxy for 'weediness'. Plants acting

412 in weedy ways - propagating quickly, spreading fast across the landscape and 'taking over'

413 (Steve) - were treated as a suspicious disruption to the ecology on their land.

415 The emergence of passive stewardship dispositions was closely associated with the failure of 416 trees planted by landholders to grow plants early in their property tenure.

418 What I did try to do and it wasn't successful, plant some deciduous trees. I planted some 419 oak trees down there... it'd be almost 20 years ago and they're no higher than about [one 420 metre tall]. They just don't grow, so I gave up on that idea. So I don't plant any other 421 trees and I haven't planted trees for years and years now. The [regenerating species are] 422 managing all right. (Emma) 
424 Emma attributed her struggle to grow introduced species to poor soil and inconsistent rainfall,

425 something to which she perceived indigenous species were well adapted. Thus, while Emma's

426 ornamental trees remained stunted (Figure 4), native bushland natural regenerated all around

427 them. Just as Hannah had experienced above, observing the contrast between the fortunes of

428 native vegetation, compared to the trees Emma had planted herself, informed a view that

429 indigenous species 'belonged', and that she should remain a passive observer. While the eight

430 landholders with passive stewardship dispositions undertook less management, they were more

431 comfortable with dynamic ecosystem change, which stood in contrast to the efforts to preserve

432 static ecologies described above.

433

434 However, for two landholders, passive stewardship derived from their experiential learning

435 made them reticent to conduct management for fear of not knowing 'the right thing to do'

436 (Sally). Sally's experience of having trees die shortly after planting them fuelled a belief that

437 she should remain a 'conscious not active' land manager. Gareth, an NRM extension officer,

438 had encountered this perspective frequently in his dealings with amenity migrants.

440 I'll come across landholders who are passionate about "their bushland", but are sort of

441 still in awe of it, and don't really interact with it. They'll walk the paths, but they'll talk

442 about "oh no, we don't go in there because it's pristine, we don't want to touch that"...

443 And I say, no, actually it's OK. You can go in to there, and indeed it's a really good

444 thing, because you'll see what's going on. (Gareth)

446 The potential for trial-and-error management failures to deter amenity migrants from pursuing

447 management like controlling weed spread has notable policy implications; we address these in 448 our concluding section. 
$450 \quad$ 4.4 The influence of wider social relations on the emergence of stewardship dispositions

451 The majority of landholders discussed sources of learning that occurred outside of their trial-

452 and-error practices, with local community environment groups, plant nurseries, books and

453 plant guides, and neighbours all contributing to their stewardship dispositions. Four

454 landholders were particularly thankful for 'invaluable' (Maddy) advice on tree planting from

455 nurseries in particular. Some participants like Maddy and Tina, actively sought out external

456 advice after their initial plantings failed, seeking information about suitable species and

457 planting arrangements for their properties. Ken, Steve, and Jeff and Claire explained a similar

458 process of seeking out advice after struggling to remove weeds on their property through hand-

459 pulling and spraying techniques. Claire had been 'dead-heading' a weed species (cutting the

460 flower off before it goes to seed) as a way of trying to control its spread - a practice she had

461 carried over from an existing interest in gardening. Having observed continual spread of the

462 weed species, Claire felt they were 'going to have to seek advice' about alternative

463 management techniques. As Larsen and Hutton (2011) found, amenity migrants appear to seek

464 out information based on specific management needs they identify that relate to their individual

465 circumstances.

467 When landholders were exposed to external advice or information about land management, this 468 advice was often tested against their experiential learning. As seen from Sam and Alice's

469 experience earlier, the decision to remove native species progressed despite identifying the

470 species as indigenous in a local native plant guide, because lived experience of surrounding

471 ecological change was prioritised over external information that conflicted with that

472 experience. However, there was some evidence of landholders changing their land

473 management through social encounters. For example, Alice and Simone took advice from 
474 neighbours on the types of tree species they should consider planting after struggling to get

475 other trees established, whilst Emma stopped removing a native shrub species she believed was

476 a weed (after observing its rapid spread) after being told by a local farmer that the species in

477 question was good bird habitat. The potential for stewardship dispositions that were grounded

478 in experiential learning to shift as a result of wider social engagement suggest that landholder

479 stewardship is 'durable yet changeable' (Kasper, 2009, p316) in the face of contradictory

480 advice. Stewardship dispositions appear capable of shifting over time in response to 'trigger

481 events', like timely interactions with other sources of knowledge when management efforts are

482 not going to plan (Sutherland et al., 2012). Yet, the power of experiential learning meant that

483 stewardship that emerged through trial-and-error could also be resistant to external knowledge.

485 The prioritisation of experiential learning over learning through social interactions may be

486 indicative of differences between the stewardship of farmers and amenity migrants. As noted

487 earlier, farmers' collective interest in maintaining productive rural landscapes can produce

488 strong social norms on acceptable management practice and facilitate knowledge sharing

489 (Yung \& Belsky, 2007). In the case of amenity migration, where landholders appear to often

490 frame management as an individual, property-centric pursuit, experiential learning may be a

491 stronger influence on the way landholders learn to be environmental stewards.

\section{5. Conclusions and implications}

494 The passive and active stewardship dispositions of amenity migrants captured here invites

495 reflection on which approach might be best for environmental management. However, the

496 findings demonstrate that attempting to judge the extent to which either active or passive

497 stewardship aligns with a notion of 'best practice' is a difficult and potentially fraught task,

498 given the complex histories of landscape modification in rural areas experiencing amenity 
499 migration (Abrams et al., 2012). Moreover, whether a passive or active stewardship approach

500 is preferable will be heavily contingent on the ecologies in question and the form and character

501 of landscape agency in each location. Rather than recommending one approach as superior for

502 the purposes of generating ecological benefits, we would suggest encouraging a reflexive

503 active stewardship disposition in environmental management for the purposes of fostering a

504 tangible and conscious connection between landholder and environment. In line with Gareth

505 and Sally's earlier reflections on passive dispositions, we believe active stewardship is

506 particularly important for helping amenity migrants to feel a sense of belonging and familiarity

507 in landscapes that are unfamiliar upon arrival.

508

509 5.1 Stewardship dispositions: the implications of spatial and temporal influences

510 Time and space were critical in the emergence of passive and active stewardship dispositions

511 through experiential learning. In terms of space, the concept of dwelling showed how the

512 property parcel was central to landholder learning about ecological function. The property

513 scale was the scale at which the environment was most 'meaningful' to participants

514 (Macnaghten, 2008). As a result, when efforts to establish garden plantings based on imported

515 management knowledge failed, the experience triggered a highly transformative experiential

516 learning process that was bounded by experience in the property space. The learning derived

517 on the property could become resistant to information and advice that came for outside this

518 space, which often related to ecological function at larger scales than the property parcel. It is

519 important for research engaging with experiential learning and stewardship to reflect on how

520 spatial scale can disproportionately shape the learning of management practitioners (Knapp \&

521 Fernandez-Gimenez, 2009). The influence of space on learning may be particularly acute when

522 management practitioners are engaging with an unfamiliar ecology or responding to an

523 unfamiliar ecological change event like drought. 
525 Emergent stewardship practices and dispositions were also bound up with the change and 526 continuity of surrounding ecologies (Cloke \& Jones 2001). Learning-by-doing requires time

527 for management interventions to materialise in the landscape and be observed and interpreted

528 by landholders (L. Head \& Muir, 2006). For Alice and Sam it was a decade before the spread

529 of pioneering shrub species prompted management interventions. For landholders like Hannah

530 and Emma, the death of early garden plantings meant experiential learning occurred rapidly.

531 Whether experiential learning is immediate or gradual, the learning that can emerge from

532 formative and specific management actions appears capable of shaping a stewardship

533 disposition that is then applied to a range of land management scenarios. In terms of the

534 interaction between experiential learning and other learning processes, time appears to make

535 landholders' experiential learning increasingly resistant to other influences on their

536 stewardship. While the walkabout method did allow reflection on changing landscapes and

537 stewardship over time, future research in this space should consider a follow-up research

538 encounter, which could provide deeper insights into temporal influences.

$540 \quad 5.2$ Building on experiential learning theory through a dwelling perspective

541 Recognising the agency of the landscape through a dwelling perspective shows how the

542 landscape is more than just a setting for the cognitive learning of individuals; it is actively

543 bound up in the process of learning to be an environmental steward. The dwelling perspective

544 provides a much needed avenue for expanding experiential learning beyond a depiction of the

545 self-contained individual learner (Seaman, 2008), complementing existing efforts to connect

546 experiential learning to wider social relations (Lankester, 2013; Leeuwis, 2004). The active

547 role of landscape in the learning process was exemplified by the way in which unanticipated

548 ecological changes that materialised from management practice could instigate experiential 
549 learning. Applications of experiential learning in research into the activities of environmental

550 management practitioners must be attentive to nonhuman agency as part of experiential

551 learning.

\section{$553 \quad \underline{5.3 \text { Implications for environmental policy in changing rural landscapes }}$}

554 Our understanding of how amenity migrants learn to be environmental stewards has

555 implications for the design and development of policy. Here we have focused specifically on

556 the influence of space and time in the emergence of stewardship dispositions, to provide

557 insights that could assist policy makers and extension officers in their direct engagements with

558 amenity migrants:

559

560 - Early engagement with landholders is important for connecting their property-centric

561 interests with landscape-scale conceptions of environmental management, before their

562 stewardship dispositions become too resistant to external advice. As has been noted

563 elsewhere, landholders involved in environmental programs often like to understand how

564 their participation in a program fits within the 'bigger picture' of conservation action at a

565 landscape scale (Cocklin et al., 2007). Outlining the bigger picture allows policy-makers

566 and extension officers to discuss ideas about landscape-scale ecological function with

567 landholders, helping to counter issues like Sam and Alice's suspicion of dynamic

568 ecological change. Early engagement with an extension officer also establishes a potential

569 ongoing source of information about land management for landholders, as they encounter

$570 \quad$ various challenges during their property tenure.

572 - The location of policy engagement with landholders is critical, given that management

573 advice may be counter to the stewardship dispositions that have emerged through 
574 experiential learning. Engaging with landholders may be most effective in the property-

575 space, where those ideas originally emerged. As the walkabout method demonstrated in a

576 research context, the physical environment can be an important catalyst for management

577 discussions as it embodies the experiences of landholders in that space over time. As such,

578 engaging landholders in management discussion in the property space could serve as a type

579 of trigger event, allowing for subtle shifts in durable stewardship disposition. Direct

580 encounters with landholders using the biophysical landscape as a learning environment

581 could also help overcome the management hesitancy of landholders like Sally, for whom

582 passive stewardship was informed by a fear of doing the wrong thing. Whilst passive

583 stewardship can mean landholders are more accepting of dynamic ecological change, there

584 is a risk that their hands off approach is resulting in benign neglect of local ecologies (Gill

585 et al., 2010). As Gareth (extension officer) noted, showing landholders that 'it's OK' to be

586 active managers may be most effectively done on the property, where the benefits can be

$587 \quad$ observed and demonstrated.

588

589 The emerging stewardship dispositions of amenity migrants reveal the powerful inter-

590 relationship of landscape agency and experiential learning in shaping land management

591 practice. In exploring this human-environment relationship, we have provided new insights for

592 the application of experiential learning in environmental management. These insights have

593 demonstrated the contribution of amenity migrants' land management practices in re-shaping

594 rural landscapes. 


\section{References}

1. Abrams, J. \& Bliss, J. C. (2013). Amenity Landownership, Land use change, and the recreation of "working landscapes." Society \& Natural Resources, 26(7), 845-859. doi:10.1080/08941920.2012.719587

2. Abrams, J.B., Gill, N., Gosnell, H., \& Klepeis, P. (2012). Re-creating the rural, reconstructing nature: an international literature review of the environmental implications of amenity migration. Conservation and Society, 10(3), 270. doi:10.4103/09724923.101837

3. ABS (Australian Bureau of Statistics). (2006). Bass Coast Shire Council community profile data. Retrieved August 2, 2012, from http://profile.id.com.au/basscoast/industries?WebID=130\&DataType $=$ en

4. Argent, N., Tonts, M., Jones, R., \& Holmes, J. (2010). Amenity-led migration in rural Australia: a new driver of local demographic and environmental change. In; G. W. Luck, R. Black, and D. Race (Eds.). Demographic change in Australia's rural landscapes. Dordrecht: Springer.

5. Armitage, D. R., Plummer, R., Berkes, F., Arthur, R. I., Charles, A. T., Davidson-Hunt, I. J., Diduck, A.P., Doubleday, N.C., Johnson. D.S., Marschke, M., McConney, P., Pinkerton, E.W., \& Wollenberg, E. K. (2009). Adaptive co-management for social-ecological complexity. Frontiers in Ecology and the Environment, 7(2), 95-102. doi:10.1890/070089

6. Berkes, F., \& Turner, N. J. (2006). Knowledge, learning and the evolution of conservation practice for social-ecological system resilience. Human Ecology, 34(4), 479-494. doi:10.1007/s10745-006-9008-2

7. Burnley, I, H., \& Murphy, P. (2004). Sea change: movement from metropolitan to arcadian Australia. Sydney: UNSW Press. 
8. Burton, R. (2012). Understanding farmers' aesthetic preference for tidy agricultural landscapes: a Bourdieusian perspective. Landscape Research, 37(1), 51-71. doi:10.1080/01426397.2011.559311

9. Burton, R., Kuczera, C., \& Schwarz, G. (2008). Exploring farmers' cultural resistance to voluntary agri-environmental schemes. Sociologia Ruralis, 48(1), 16-37. doi:10.1111/j.1467-9523.2008.00452.x

10. Cadieux, K. V. (2011). Competing discourses of nature in exurbia. GeoJournal, 76, $341-$ 363. doi:10.1007/s10708-009-9299-0

11. Cadieux, K. V., \& Hurley, P. T. (2009). Amenity migration, exurbia, and emerging rural landscapes: global natural amenity as place and as process. GeoJournal. doi:10.1007/s10708-009-9335-0

12. Cammack, P. J., Convery, I., \& Prince, H. (2011). Gardens and birdwatching: recreation, environmental management and human-nature interaction in an everyday location. Area, 43(3), 314-318. doi:10.1111/j.1475-4762.2011.00992.x

13. Cerbone, D.R. (2008). Heidegger: a guide for the perplexed. New York: Bloomsbury.

14. Cloke, P., \& Jones, O. (2001). Dwelling, place, and landscape: an orchard in Somerset. Environment and Planning A, 33(4), 649-666. doi:10.1068/a3383

15. Cocklin, C., Mautner, N., \& Dibden, J. (2007). Public policy, private landholders: Perspectives on policy mechanisms for sustainable land management. Journal of Environmental Management, 85, 986-998. doi:10.1016/j.jenvman.2006.11.009

16. Cooke, B., Langford, W. T., Gordon, A., \& Bekessy, S. (2012). Social context and the role of collaborative policy making for private land conservation. Journal of Environmental Planning and Management, 1-17. doi:10.1080/09640568.2011.608549 
17. Curry, G. N., Koczberski, G., \& Selwood, J. (2001). Cashing out, cashing in: rural change on the south coast of Western Australia. Australian Geographer, 32(1), 109-124. doi:10.1080/00049180020036268

18. Erickson, D. (2002). Woodlots in the rural landscape: landowner motivations and management attitudes in a Michigan (USA) case study. Landscape and Urban Planning, 58(2-4), 101-112. doi:10.1016/S0169-2046(01)00213-4

19. Farmar-Bowers, Q., \& Lane, R. (2009). Understanding farmers'strategic decision-making processes and implications for biodiversity conservation policy. Journal of Environmental Management, 92, 1135-1144.

20. Gill, N. (2013). Making country good: stewardship and environmental change in central Australian pastoral culture. Transactions of the Institute of British Geographers. doi:10.1111/tran.12025

21. Gill, N., Klepeis, P., \& Chisholm, L. (2010). Stewardship among lifestyle oriented rural landowners. Journal of Environmental Planning and Management, 53(3), 317-334. doi:10.1080/09640561003612890

22. Gosnell, H. (2011). Amenity migration: diverse conceptualizations of drivers, socioeconomic dimensions, and emerging challenges. GeoJournal, 76(4), 303-322. doi:10.1007/s10708-009-9295-4

23. Greiner, R., \& Gregg, D. (2011). Farmers' intrinsic motivations, barriers to the adoption of conservation practices and effectiveness of policy instruments: empirical evidence from northern Australia. Land Use Policy, 28(1), 257-265.

doi:10.1016/j.landusepol.2010.06.006

24. Head, L., \& Atchison, J. (2008). Cultural ecology: emerging human-plant geographies. Progress in Human Geography, 33(2), 236-245. doi:10.1177/0309132508094075 
25. Head, L., \& Muir, P. (2006). Suburban life and the boundaries of nature : resilience and rupture in Australian backyard gardens. Transactions of the Institute of British Geographers, 31, 505-524.

26. Heiddegger, M. (1971). Poetry, language, thought. New York: Harper and Row.

27. Holmes, J. (2006). Impulses towards a multifunctional transition in rural Australia: Gaps in the research agenda. Journal of Rural Studies, 22(2), 142-160. doi:10.1016/j.jrurstud.2005.08.006

28. Ingold, T. (2000). The perception of the environment: essays on livelihood, dwelling and skill. London: Routledge.

29. Junge, X., Lindemann-Matthies, P., Hunziker, M., \& Schüpbach, B. (2011). Aesthetic preferences of non-farmers and farmers for different land-use types and proportions of ecological compensation areas in the Swiss lowlands. Biological Conservation, 144(5), 1430-1440. doi:10.1016/j.biocon.2011.01.012

30. Keen, M., \& Mahanty, S. (2006). Learning in sustainable natural resource management: challenges and opportunities in the Pacific. Society \& Natural Resources, 19(6), 497-513. doi:10.1080/08941920600663896

31. Klepeis, P., Gill, N., \& Chisholm, L. (2009). Emerging amenity landscapes: Invasive weeds and land subdivision in rural Australia. Land Use Policy, 26(2), 380-392. doi:10.1016/j.landusepol.2008.04.006

32. Knapp, C. N., \& Fernandez-Gimenez, M. E. (2009). Knowledge in practice: documenting rancher local knowledge in Northwest Colorado. Rangeland Ecology \& Management, 62(6), 500-509. doi:10.2111/08-175.1

33. Knoot, T.G., Schulte, L.A, \& Rickenbach, M. (2010). Oak conservation and restoration on private forestlands: negotiating a social-ecological landscape. Environmental Management, 45(1), 155-64. doi:10.1007/s00267-009-9404-7 
34. Kolb, D.A., (1984). Experiential learning: experience as the source of learning and development. Prentice-Hall, Englewood Cliffs.

35. Kolb, D.A., Boyatzis, R.E., \& Mainemelis, C., (2001). Experiential learning theory: previous research and new directions. In: Sternberg, R.J., Zhang, L.F. (Eds.). Perspectives on cognitive, learning, and thinking styles. New Jersey, Lawrence Erlbaum, p. 227-247

36. Kondo, M. C., Rivera, R., \& Rullman, S. (2012). Protecting the idyll but not the environment: Second homes, amenity migration and rural exclusion in Washington State. Landscape and Urban Planning, 106(2), 174-182. doi:10.1016/j.landurbplan.2012.03.003

37. Lane, R. (1997). Oral histories and scientific knowledge in understanding environmental change. Australian Geographical Studies, 35(2):195-205.

38. Lankester, A. J. (2013). Conceptual and operational understanding of learning for sustainability: a case study of the beef industry in north-eastern Australia. Journal of Environmental Management, 119, 182-93. doi:10.1016/j.jenvman.2013.02.002

39. Larsen, S., \& Hutton, C. (2011). Community discourse and the emerging amenity landscapes of the rural American West. GeoJournal, 77(5), 651-665. doi:10.1007/s10708011-9410-1

40. Lawrence, G., Richards, C., \& Cheshire, L. (2004). The environmental enigma: why do producers professing stewardship continue to practice poor natural resource management? Journal of Environmental Policy \& Planning, 6(3-4), 251-270. doi:10.1080/1523908042000344069

41. Leeuwis, C. (2004). Communication for rural innovation: rethinking agricultural extension. Blackwell Science Ltd, Oxford.

42. López-i-Gelats, F., Tàbara, J. D., \& Bartolomé, J. (2009). The rural in dispute: Discourses of rurality in the Pyrenees. Geoforum, 40(4), 602-612. doi:10.1016/j.geoforum.2009.04.008 
43. Macnaghten, P. (2008). Embodying the environment in everyday life practices. The Sociological Review, 51(1), 63-84. doi:10.1111/1467-954X.00408

44. Macnaghten, P., \& Urry, J. (1998). Contested natures. London: Sage.

45. Meadows, J., Herbohn, J., \& Emtage, N. (2013). Supporting cooperative forest management among small-acreage lifestyle landowners in Southeast Queensland, Australia. Society \& Natural Resources, 26(7), 745-761. doi:10.1080/08941920.2012.719586

46. Mendham, E., \& Curtis, A. (2010). Taking over the reins: trends and impacts of changes in rural property ownership. Society \& Natural Resources, 23(7), 653-668. doi:10.1080/08941920801998893

47. Mendham, E., Curtis, A., \& Millar, J. (2012). The natural resource management implications of rural property turnover. Ecology and Society, 17(4), art5. doi:10.5751/ES05071-170405

48. Nordlund, A.M., \& Garvill, J. (2002). Value structures behind proenvironmental behavior. Environment and Behavior, 34(6), 740-756. doi:10.1177/001391602237244

49. Palis, F.G. (2006). The role of culture in farmer learning and technology adoption: a case study of farmer field schools among rice farmers in central Luzon, Philippines. Agriculture and Human Values, 23(4), 491-500. doi:10.1007/s10460-006-9012-6

50. Pannell, D., Marshall, G. R., Curtis, A., Barr, N., Vanclay, F., \& Wilkinson, R. (2006). Understanding and promoting adoption of conservation practices by rural landholders. Australian Journal of Experimental Agriculture, 46(11), 1407. doi:10.1071/EA05037

51. Phillips, M. (1993). Rural gentrification and the processes of class colonisation. Journal of Rural Studies, 9(2), 123-140.

52. Robbins, P. (2007). Lawn people: how grass, weeds and chemicals make us who we are. Philadelphia: Temple University Press. 
53. Reed, M., Evely, A., Cundill, G., Fazey, I. R. A., Glass, J., \& Laing, A. (2010). What is social learning? Ecology and Society. 15(4).

54. Strang, V. (2010). Mapping histories: cultural landscapes and walkabout methods. In: A. Smith and S. Aswani (Eds.). Environmental social science: methods and research design. Cambridge University Press, p. 132-156.

55. Trigger, D., Toussaint, Y., \& Mulcock, J. (2010). Ecological restoration in Australia: environmental discourses, landscape ideals, and the significance of human agency. Society \& Natural Resources, 23(11), 1060-1074. doi:10.1080/08941920903232902

56. Urquhart, J., \& Courtney, P. (2011). Seeing the owner behind the trees: A typology of small-scale private woodland owners in England. Forest Policy and Economics, 13(7), 535-544. doi:10.1016/j.forpol.2011.05.010

57. Van Auken, P. M. (2010). Seeing, not participating: viewscape fetishism in American and Norwegian rural amenity areas. Human Ecology, 38(4), 521-537. doi:10.1007/s10745-0109323-5

58. Van Herzele, A., Dendoncker, N., \& Acosta-Michlik, L. (2010). Mobilisation capacity for agri-environmental management. Journal of Environmental Management, 1-10. doi:10.1016/j.jenvman.2010.11.013

59. Worrell, R., \& Appleby, M. C. (2000). Stewardship of natural resources: definition, ethical and practical aspects. Journal of Agricultural and Environmental Ethics, 12, 263-277.

60. Yung, L., \& Belsky, J. M. (2007). Private property rights and community goods: negotiating landowner cooperation amid changing ownership on the Rocky Mountain front. Society \& Natural Resources, 20(8), 689-703. doi:10.1080/08941920701216586 
Table 1. Details of research participants (Names are pseudonyms) including where they have migrated from and the basic landscape characteristics of their property.

\begin{tabular}{|c|c|c|c|c|c|}
\hline Participant/s & Age & $\begin{array}{l}\text { Landscape setting prior to amenity } \\
\text { migration }\end{array}$ & Characteristics of the property landscape & Property size & $\begin{array}{l}\text { Length of } \\
\text { Tenure }\end{array}$ \\
\hline Jim \& Beatrice & $40-49$ & $\begin{array}{l}\text { Suburban Melbourne (Beatrice) and farm in } \\
\text { local area (Jim) }\end{array}$ & Intact forest vegetation; cleared paddock & $\sim 10$ hectares & 15 years \\
\hline Steve & $50-59$ & Residential property in small rural town & Intact open woodland area; revegetated section & 5 hectares & 9 years \\
\hline Kelly & $60-69$ & Suburban Melbourne & Intact remnant forest & 8 hectares & 11 years \\
\hline $\mathbf{L i z}$ & $50-59$ & $\begin{array}{l}\text { Rural upbringing before living overseas - } \\
\text { returned to rural region as amenity landholder }\end{array}$ & $\begin{array}{l}\text { Intact forest sections; cleared paddock; passively } \\
\text { regenerating ecologies }\end{array}$ & 22 hectares & $20+$ years \\
\hline Rob & $50-59$ & $\begin{array}{l}\text { Suburban upbringing - amenity property was } \\
\text { holiday house that is now occupied full time }\end{array}$ & Regenerated forest vegetation; cleared paddocks & 6 hectares & $20+$ years \\
\hline Trevor & $70-79$ & $\begin{array}{l}\text { Long-time farmer who retired on his now sub- } \\
\text { divided farmland }\end{array}$ & Degraded remnant patches; revegetated area & 40 hectares & $20+$ years \\
\hline Alex \& Simone & $30-39$ & Suburban Melbourne & $\begin{array}{l}\text { Intact forest with thick shrub layer; cleared paddock; } \\
\text { patch of degraded remnant vegetation }\end{array}$ & $\sim 15$ hectares & 14 years \\
\hline Emma & $70-79$ & $\begin{array}{l}\text { Suburban Melbourne upbringing; lived on } \\
\text { residential property in regional centre prior }\end{array}$ & $\begin{array}{l}\text { Re-growth eucalypt forest with dense patches of } \\
\text { understorey }\end{array}$ & 6 hectares & 26 years \\
\hline Sally & $40-49$ & Suburban Melbourne & Intact forest with dense shrubs; cleared paddock & $\sim 10$ hectares & 8 years \\
\hline Karen & $70-79$ & $\begin{array}{l}\text { Suburban Melbourne - amenity property was } \\
\text { holiday house that is now occupied full time }\end{array}$ & Degraded remnant forest; cleared paddock & 10 hectares & 13 years \\
\hline Ken & $50-59$ & $\begin{array}{l}\text { Suburban upbringing }- \text { spent much of adult life } \\
\text { working in rural regions }\end{array}$ & $\begin{array}{l}\text { Remnant forest; cleared paddock and regenerating } \\
\text { grassland }\end{array}$ & 130 hectares & 6 years \\
\hline Maddy & $50-59$ & $\begin{array}{l}\text { Suburban Melbourne upbringing - spent time } \\
\text { on family farm growing up }\end{array}$ & Revegetated forest; cleared paddock & 30 hectares & 8 years \\
\hline Alice \& Sam & $50-59$ & $\begin{array}{l}\text { Home business operators on a rural amenity } \\
\text { property (suburban Melbourne upbringing) }\end{array}$ & Intact open woodland with sparse understorey & $\sim 20$ hectares & 14 years \\
\hline Pauline \& Allan & $40-49$ & Suburban Melbourne & Cleared paddock; linear tree plantings & 116 hectares & 12 years \\
\hline Dan & $70-79$ & Long-time farmer who retired on his farm & Open paddock; revegetated linear tree plantings & 40 hectares & 28 years \\
\hline William & $40-49$ & Suburban Melbourne & Intact forest vegetation (degraded) & 2 hectares & 17 years \\
\hline Lauren & $40-49$ & $\begin{array}{l}\text { Suburban Melbourne (grew up on a farm in the } \\
\text { region) }\end{array}$ & $\begin{array}{l}\text { Intact and re-growth forest; cleared paddock; tree } \\
\text { plantings }\end{array}$ & 40 hectares & 22 years \\
\hline Hannah & $40-49$ & Suburban Melbourne & Re-growth forest and small cleared paddocks & 8 hectares & 18 years \\
\hline Nick & $50-59$ & Residential property in large regional town & $\begin{array}{l}\text { Degraded remnant vegetation; revegetation; cleared } \\
\text { paddock; orchard }\end{array}$ & 60 hectares & 7 years \\
\hline Jeff \& Claire & $50-59$ & Residential property in large regional town & Regenerating remnant; cleared paddock & $\sim 80$ hectares & 14 years \\
\hline Tina & $50-59$ & Suburban Melbourne & Revegetated patch; paddock; small hazelnut orchard & 7 hectares & 22 years \\
\hline
\end{tabular}




\section{List of Figures:}

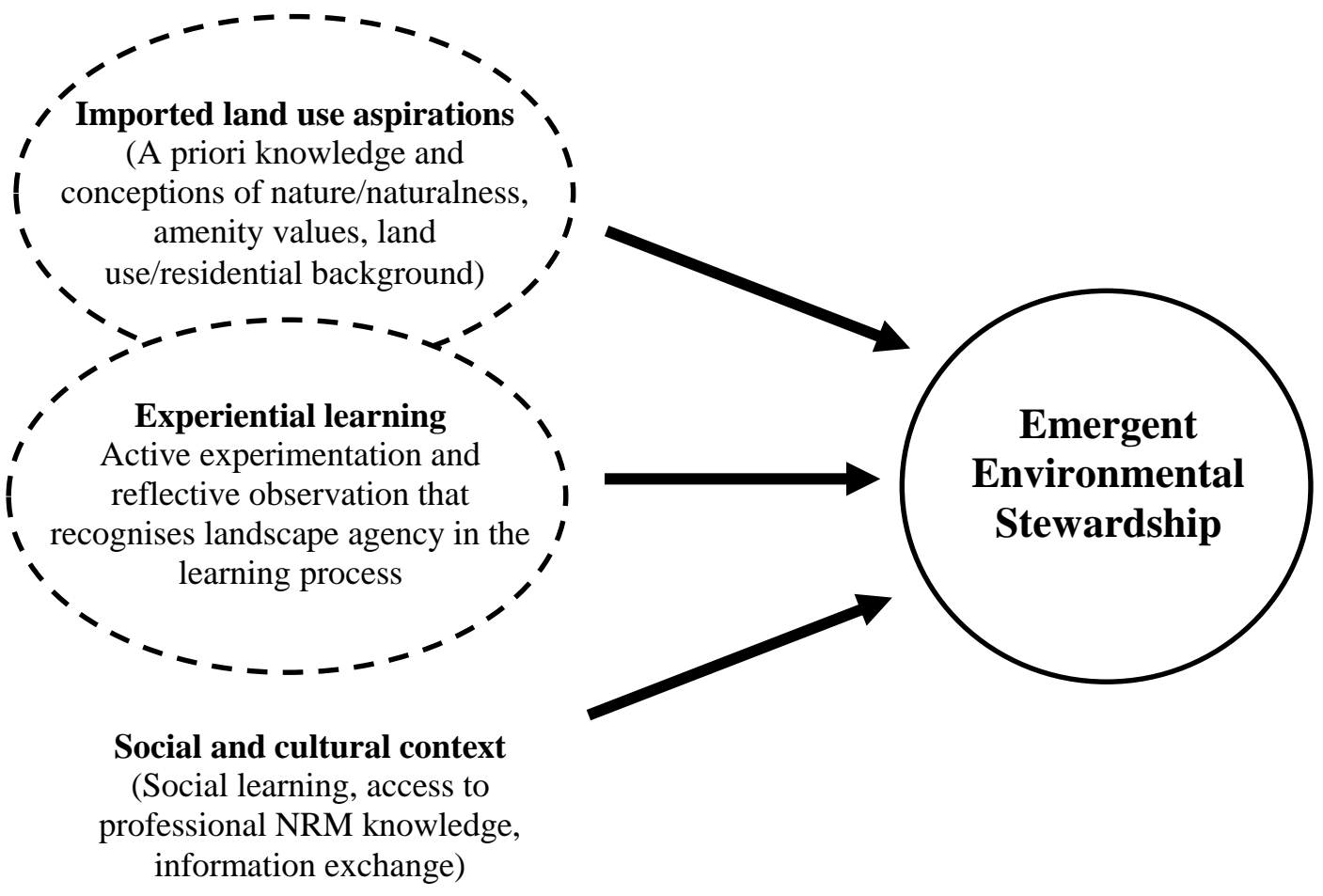

Figure 1. Integrating nonhuman agency into learning about management practice, and the emergence of landholders' notions of stewardship. The dashed and overlapping lines reflect that the influences on emergent environment stewardship are not isolated and discrete, but open and inter-related. 


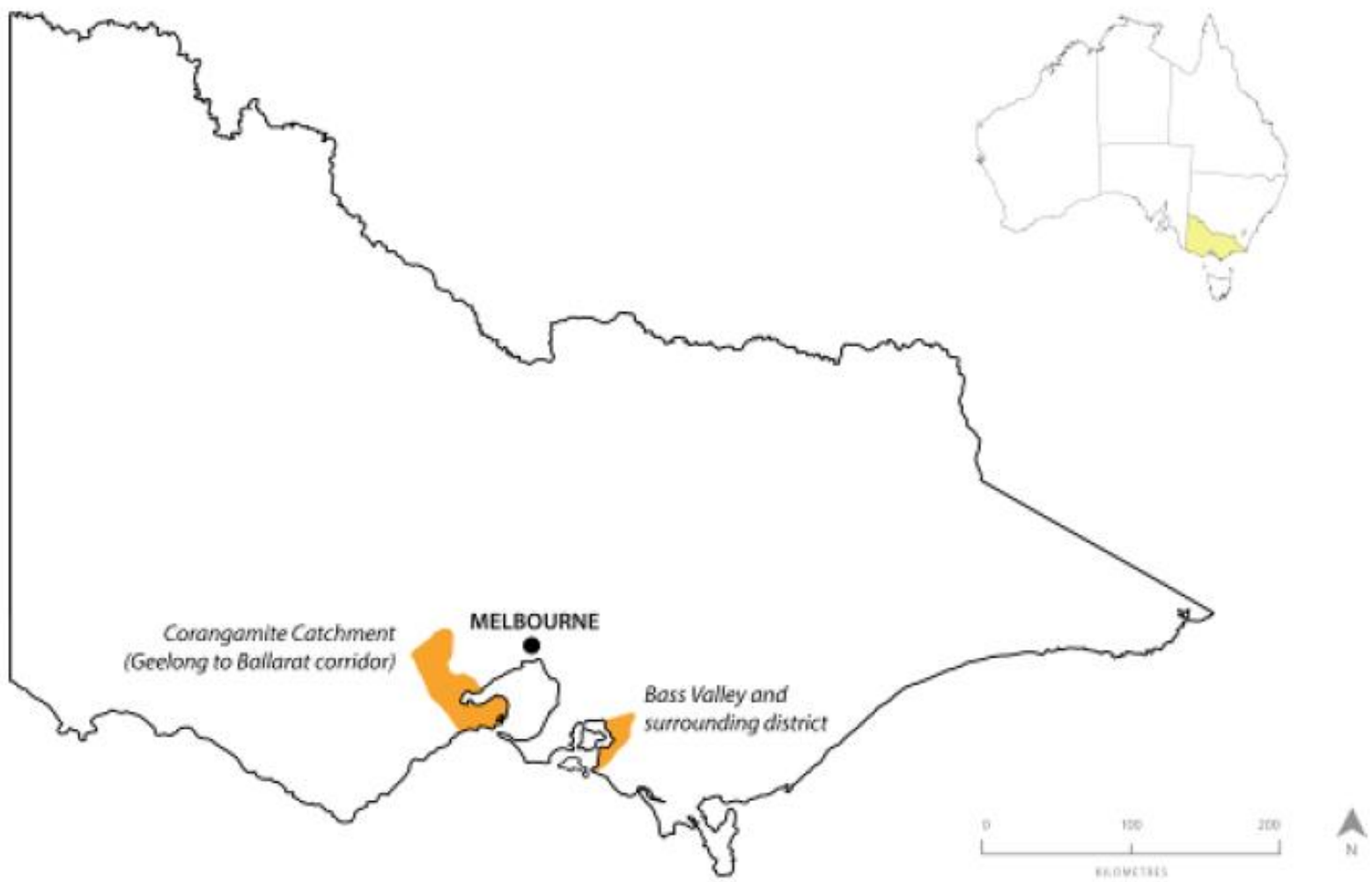

Figure 2. The two study areas within Melbourne's hinterland that were the focus of this research. 


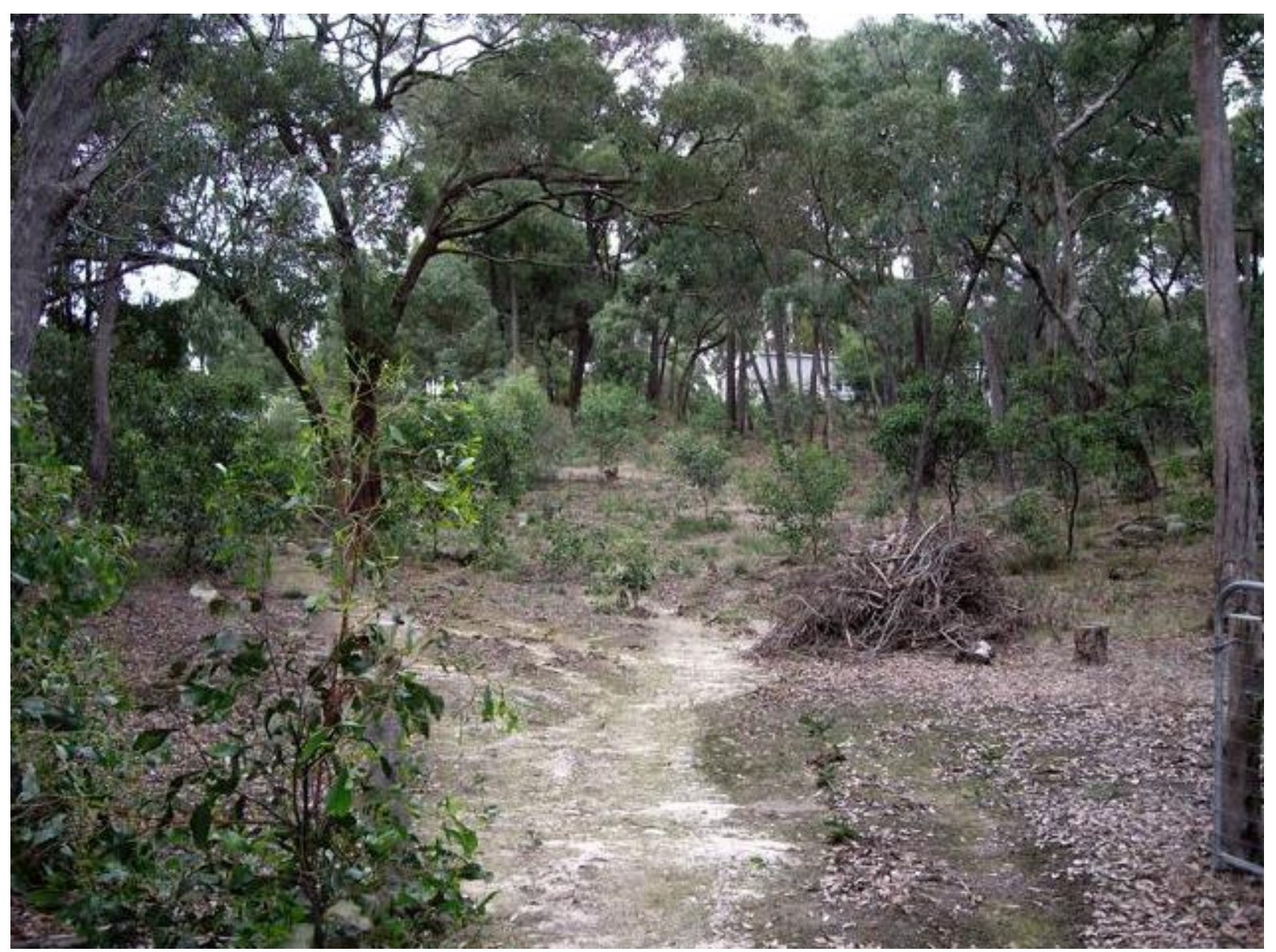

Figure 3. The natural regeneration of native acacia's (small shrubs in the foreground) resulted in efforts by Alice and Sam to remove them - a pile of recently cleared acacia's can be seen centre-right. A decade of living in a drought-effected landscape had generated a notion of the Australian bush as a static ecology. 


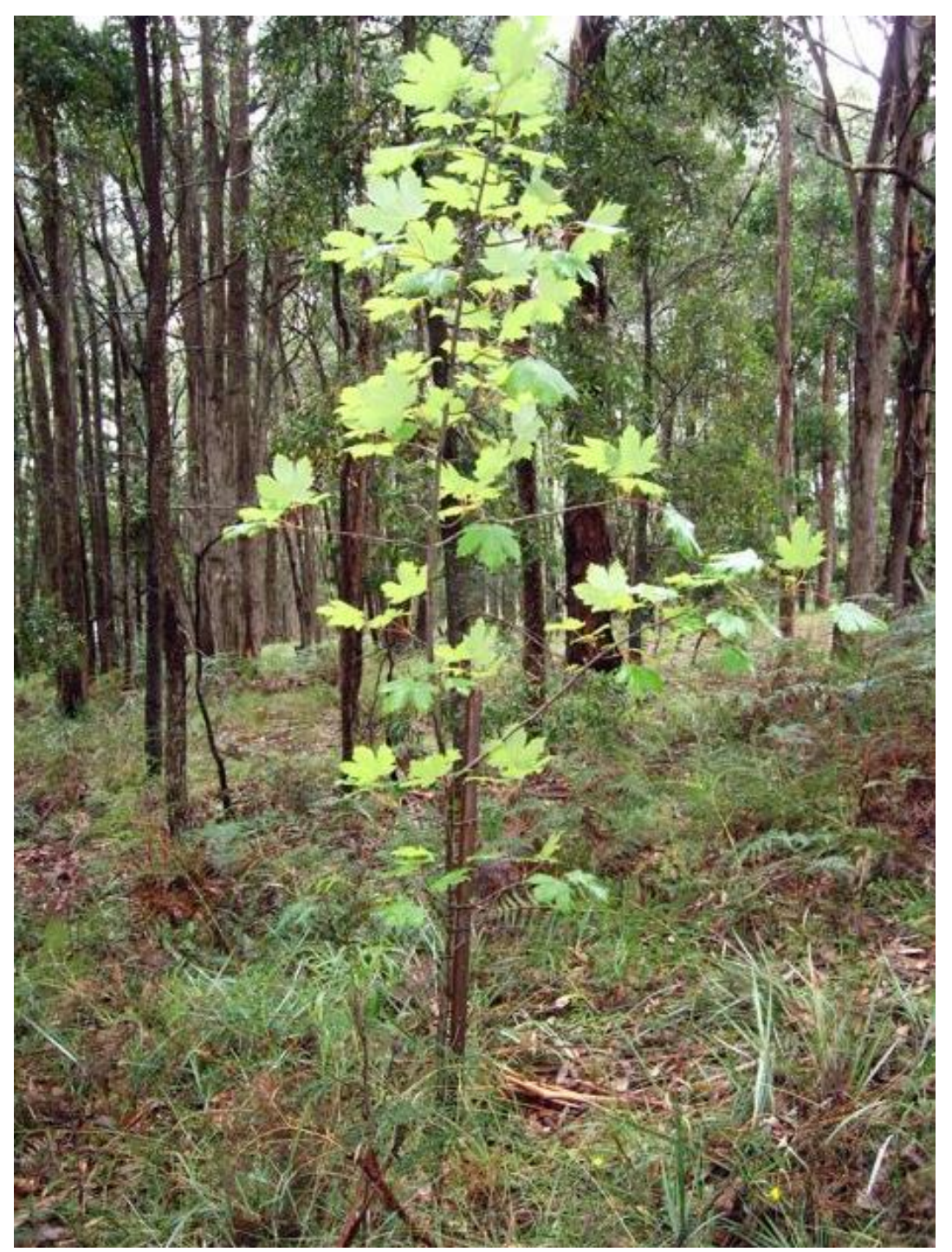

Figure 4. The contrast between the stunted growth of the Japanese maple (foreground) planted by Emma, in contrast to the flourishing regeneration of surrounding bushland, cemented Emma's passive stewardship disposition. 